\title{
Implant Insertion Methods and Periimplant Tissues - Experimental Study
}

\author{
Smiljana Matić, Novak Stamatović, Zoran Tatić \\ and Aleksandra Petković-Ćurčin \\ Military Medical Academy \\ Serbia
}

\section{Introduction}

The replacement of missing teeth with dental implants has become predictable treatment modality over the past several decades. The function of dental implants depends on the process of osseointegration, defined by Brånemark (Brånemark, 1985, as cited in Abrahamsson \& Cardaropoli, 2006) as „direct structural and functional connection between living ordered bone and the surface of load carrying implant". The process through which osseointegration is achieved depends on several factors, such as biocompatibility of the metal used as well as the design and surface characteristics of the implant, the condition of the implant socket, the surgical technique used and the loading conditions applied (Abrahamsson \& Cardaropoli, 2006).

Endosteal implants are available in various designs, forms and materials. The earliest implant designs were one-component devices, i.e. implant body and implant abutment were connected in a single unit. Those implants could only be inserted in one-stage surgical method and are collectively referred to as "one-stage" or non-submerged implant systems. When inserted, implants penetrate through the oral mucosa into the oral cavity thus risking the possible contamination and/or early loading that could result in implant failure.

Within the past five decades numerous types of implant designs have evolved. Almost all of them have a common characteristic: they consist of two parts - the implant body and the implant abutment or transmucosal part. The first part (implant body) is placed into the bone socket and covered with mucoperiosteal flap. The second part (implant abutment) is connected to the implant after a period of healing in the secondary surgical procedure. These designs are recommended for so called "two-stage" or submerge surgical approach, and the components of the soft tissue cover, epithelial and subepithelial tissue, act as a barrier between the internal (bone tissue) and external (oral cavity) environment.

The studies on both surgical methods have been well documented (Adell et al., 1990, as cited in Heydenrijk et al., 2002; Lindquist et al., 1996; Ericsson et al., 1996; Buser et al., 1996; Levy et al., 1996; Brägger et al., 1998; Abrahamsson et al., 1999; Hermann et al., 2001; Lindquist et al., Heydenrijk et al., 2002).

On the basis of early research in dogs, Brånemark and his coworkers introduced submerged implant placement believing it was one of the key prerequisites for osseointegration (Weber \& Cochran, 1998). Namely, implants were placed under cover of the oral mucosa for a healing period of 3-6 months and after that period a second surgical procedure was 
performed i.e. the implant exposure and transmucosal components (implant abutments) were placed on the implants. Implants that accidentally became exposed to the oral cavity through wound dehiscence exhibited less favorable periimplant healing than the implants that had been submerged under oral mucosa. This concept, which requires a second stage procedure, is still followed today. An opportunity exists at the second stage surgery to correct soft tissue defects, poor soft tissue relationships, poor implant placement and bone defects (Fig. 1).

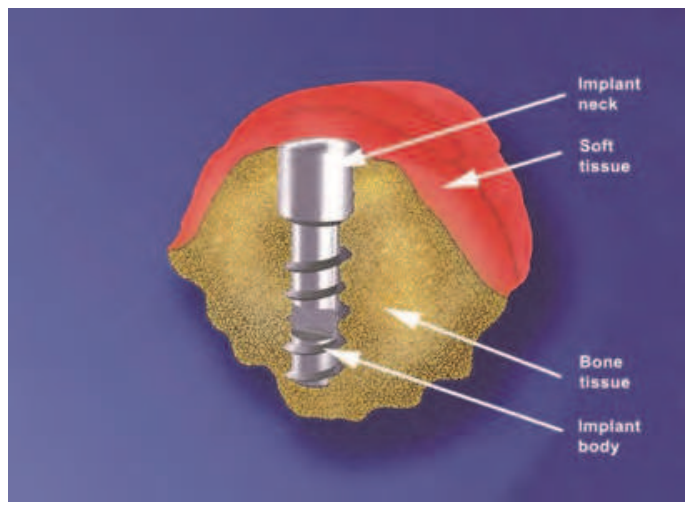

Fig. 1. Two-stage implant insertion method

However, Schroeder and al. (Schroeder, 1981, as cited in Weber \& Cochran, 1998) demonstrated in the late 1970s that non-submerged or one-stage surgical method allows successful outcome of implant insertion, i.e. successful osseointegration. After the insertion the implant penetrates through the gingival tissue into the oral cavity and it is covered with the healing cap which does not interfere with the opposing or adjacent teeth. The fact that only one surgical intervention is necessary allows for soft tissue healing to the transmucosal portion of the implant by primary intention from the moment of implant insertion. This simplified method which eliminates the need for a re-entry (second surgery) is more attractive to both patients and clinicians (Fig. 2).

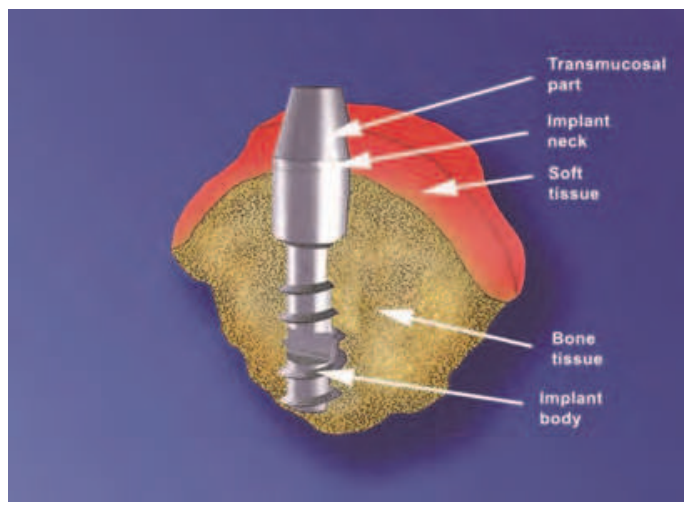

Fig. 2. One-stage implant insertion method 
For a long time it was considered that implant failure was a result of soft tissue ingrowth in the coronal aspect of bony implant bed, inflammatory infiltrate, granulation tissue, bone resorption and implant mobility that was caused by the implant communication to the oral cavity.

It is now recognized that the requirement to submerge the implant during healing is not obligatory, and even has the advantages over submerged approach including: 1) the lack of secondary surgical intervention to connect the implant body and transgingival component; 2) a more mature soft tissue healing due to avoiding the second stage surgery; 3 ) the lack of an interface/microgap between the implant and the abutment at or below the alveolar crest level; 4) healed periimplant mucosa is not disturbed with second stage procedure for abutment placement or abutment exchanges; 5) during the osseointegration period the implants are accessible for clinical monitoring; 6) cost and time benefit advantage (Heydenrijk et al., 2002). However, one-stage implantation is not preferred treatment modality in the cases of: 1) prevention of undesirable implant loading during the osseointegration period when implants are inserted in low-density bone; 2) alveolar ridge augmentation procedures or guided bone regeneration with simultaneous implant placement when the wound has to be closed perfectly to prevent the infection of bone or membrane exposure; 3 ) integrated implant abutment interference with opposing jaw (in the case of one-piece implant design).

A review of literature reveals that there is no agreement as to which of these two surgical methods has achieved better outcome.

\section{Experimental research}

Numerous reports have compared the submerged and non-submerged implant types in animal models (Ericsson et al., 1996; Weber et al., 1996; Abrahamsson et al., 1996, 1999; Levy et al., 1996; Fiorellini et al., 1999; Moon et al., 1999; Hermann et al., 2000; Berglundh et al., 2007). The amount of scientific work was focused on the achieving and maintaining a healthy relationship of dental implants to the surrounding hard and soft tissues over extended periods. To evaluate osseointegration of dental implants by animal studies many methods have been established: radiographic evaluation of bone healing, pathohistological, immunohistochemical and histomorphometric analyses. Radiographic evaluations provide the results of periimplant bone changes, i.e. the differences of periimplant bone levels. Histomorphometric analysis is the measurement of direct bone-to-implant contact without connective tissue interposition, but all these analyses include no information about functional and structural bone architecture, bone maturity or inflammatory signs. Also, because the implants are transmucosal devices and periimplant tissues are expected to act as a barrier, pathohistological evaluations of soft tissues around dental implants were performed in order to examine the morphologic characteristics of epithelial and subepithelial tissue.

\subsection{Studies on periimplant soft tissue}

The role of gingival epithelium in forming a biologic seal is of great importance in implant dentistry. This seal must be effective enough to prevent the ingress of bacterial plaque, toxins, oral debris and other substances taken into the oral cavity. The initial breakdown of soft tissue was first seen around implant abutments as gingival inflammatory reaction that was followed by osteoclastic activity of underlying hard tissue and chronic resorption of the supporting bone. 
James and Kelln were the first to begin a systemic study to investigate gingival attachment to the implant (James \& Kelln, 1974). Although they investigated oral implants made of Vitalium (stainless steel) they concluded that an adhesion exists at the interface between the junctional epithelial cells and the penetrating implant surfaces.

Current concepts of the biologic formation of mucosal attachment are based on scientific investigations using a combination of light and electron microscopy. Periimplant epithelial tissue most closely resembles that of the natural dentition. The oral epithelium lines the lateral surface of the gingival sulcus as sulcular epithelium. Its apical part is lined with the coronal cells of the junctional epithelium which provides an epithelial union between the implant and the surrounding gingival tissue. The junctional epithelium adheres to the implant surface through a basal lamina and hemidesmosomes thus preventing external agents from moving into the internal environment of the jaw. Long-term implant maintenance depends significantly on the achievement and preservation of this attachment.

In our experimental study nine dogs (German shepherds), mean age: 4,5 years, mean weight: $32 \mathrm{~kg}$ were used. In the first experimental phase third and forth lower premolars were extracted bilaterally. After a healing period of eight weeks in the second phase the implants were inserted. Using split mouth design 36 c.p. (commercially pure) titanium implants were inserted using one-stage surgical method on the right mandibular side and two-stage method on the left side respectively. Three months after the implantation the animals were sacrificed and the third experimental phase - pathohistological analysis was performed.

Analyses were performed on 90 specimens from the two soft tissue regions (epithelial and subepithelial ttissue) thus comprising 180 specimens. Semi-quantitative analysis was performed for each site (evaluation of basal membrane degradation, inflammatory cell infiltration, tissue necrosis, number of blood vessels, appearance of blood vessel walls) and graded. Quantitative analyses of pathohistological findings were performed according to the established grading indices for each evaluated region. Outcomes of two surgical methods were compared using non-parametric Wilcoxon-Mann-Whitney rank-sum test for two small independent samples.

The analysis of epithelial tissue: According to the results on the basis of descriptive statistics better results were achieved by one-stage surgical method, but there were no statistically significant differences between the two applied surgical methods. Pathohistological analyses of 9 specimens inserted in one-stage approach revealed preserved basal membranes in 7 sections, massive inflammatory cell infiltrates in 2 specimens, complete tissue necrosis in 2 and partial in 3 sections (Fig. 3).

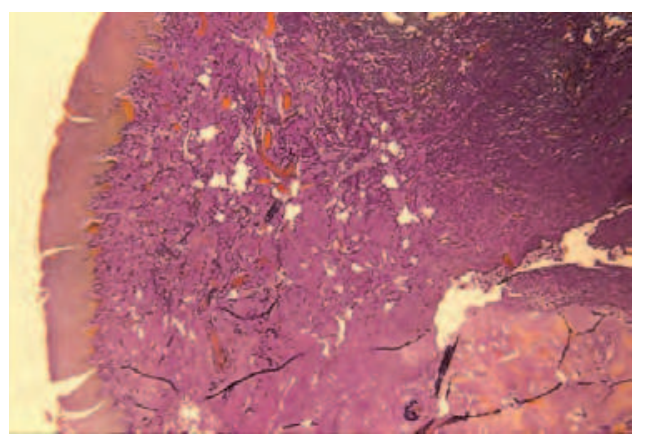

Fig. 3. Preserved epithelial tissue with basal membrane. Presence of inflammatory cells with initial necrotic lesions in subepithelial connective tissue (HE X 40). 
Regarding the findings of two-stage implants, the absence of epithelial tissue, marked inflammatory infiltrate and complete necrosis were observed in 6 specimens. Basal membrane structure was preserved in only 3 sections (Fig. 4).

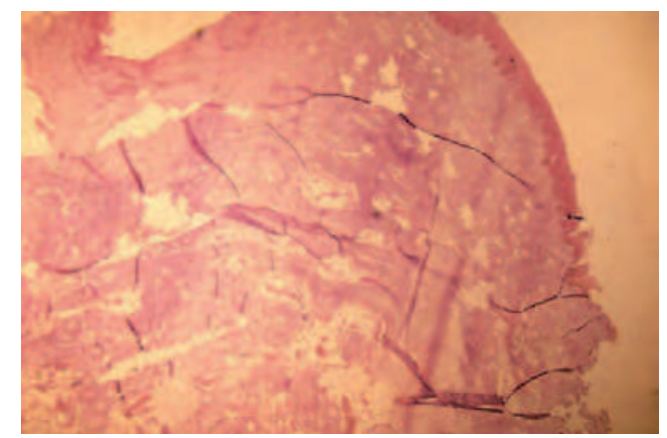

Fig. 4. Partial necrosis of gingival epithelial tissue, degradation of basal membrane, partial inflammatory cell infiltrate and initial necrosis (HE X 40)

The analysis of subepithelial tissue: According to the results on the basis of descriptive statistics, better results were achieved by one-stage surgical method regarding the number of blood vessels and vascular volume, while regarding blood vessel walls and inflammatory cell infiltrate, two methods achieved identical results. No statistically significant difference was found between the two methods. Pathohistological analyses of the implants inserted in one-stage method revealed marked neovascularization, dilated blood vessels with thick walls and inflammatory infiltrate in 3 specimens (Fig. 5).

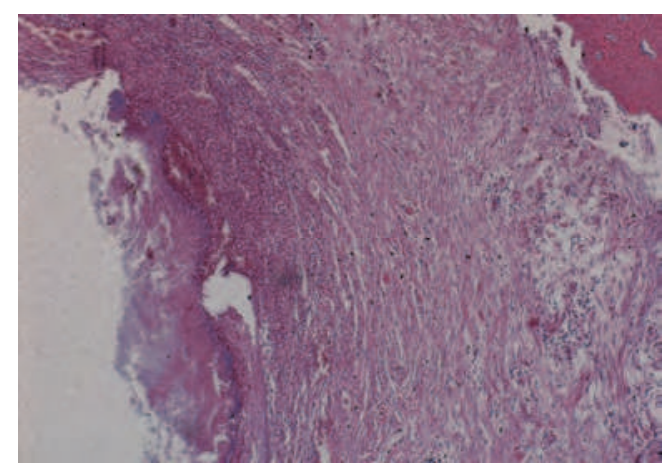

Fig. 5. Subepithelial connective tissue saturated with chronic inflammatory cells and increased vascular proliferation and dilatation (HE X 40)

Increased number of blood vessels was found in 6 specimens and marked inflammation in 4 sections of the implants inserted in two-stage method (Fig. 6). 


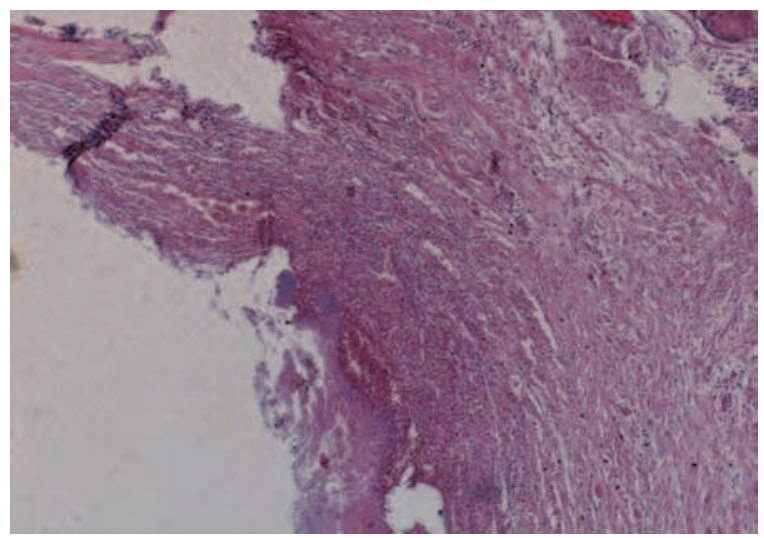

Fig. 6. Presence of partially necrotic epithelial tissue and torn subepithelial connective tissue with necrotic lesions, marked inflammatory cell infiltrate and increased vascular proliferation (HE X 40)

Dynamic changes that occur during soft tissue healing process are related to the periimplant sulcus depth, connective tissue-implant contact and the length of periimplant epithelial attachment (Buser at al., 1990; Cochran et al., 1997).

In a beagle dog study of crystal sapphire implants that were placed in one-stage procedure Fartash et al. (Fartash et al., 1990) observed discrete inflammatory infiltrate in periimplant soft tissue, while Chavrier et al. (Chavrier et al., 1994, as cited in Weber \& Cochran, 1998) observed inflammatory cells in approximately half the biopsies in their study on experimental dogs. Buser et al. (Buser at al., 1990) detected the presence of periimplant epithelial attachment in one-stage implants in experimental dogs, while Abrahmsson et al. (Abrahamsson et al., 1996, 1999) in their similar experimental studies reported that surgical method had not influence on the formation and structure of periimplant soft tissue. Weber et al. comparing non-submerged and submerged implants in beagle dogs, found significant differences between implant types. In every case where the implant was initially submerged, the epithelium was found apical to the interface (microgap) between the implant and transgingival abutment. Attachment level for non-submerged implants was located more coronally compared to submerged implants. Comparing one- and two-stage implants statistically, the authors concluded that there was a significant difference in position and epithelium extension between the two methods (Weber et al., 1996).

In their review article Weber and Cochran (Weber \& Cochran, 1998) described in details the significance of soft tissue response to submerged and non-submerged osseointegrated implants. Periimplant epithelium was described as junctional epithelium, in many ways analogous to the natural tooth and no difference between the methods of insertion was observed.

Moon et al. in their experimental study in dogs examined soft tissue attachment to dental implants inserted in one-stage method. The attachment was comprised of two portions: marginal junctional epithelium and connective tissue. Epithelium was observed in all examined specimens. The authors consider the connective tissue that is in direct contact with the implant surface and located apically of junctional epithelium significantly more 
important. The portion of connective tissue which is next to implant surface is characterized by its absence of blood vessels and abundance of fibroblasts. The authors assume that the fibroblast rich region is "responsible" for establishment and maintenance of proper seal between oral environment and periimplant bone (Moon et al. 1999).

Herman et al. (Hermann et al., 2000) in their research on one- and two-stage implantation concluded that implant abutment/interface had an impact on gingival position and periimplant sulcus depth. Placing the microgap (the connection of the abutment and the implant body) below the bone level significantly increased the forming of infrabony periimplant pockets. If the microgap was placed $0,5-1,0 \mathrm{~mm}$ below the bone level, bone resorption was increased. Microbial contamination of the microgap associated with micromovement of the implant can cause the bone resorption and chronic inflammation of the adjacent tissues. That is the reason it is not recommendable to place two-stage implants with microgap positioned apically in order to avoid negative effects on periimplant tissues. This problem has not been reported for transmucosally placed one-stage implants.

Regarding the morphogenesis of periimplant mucosal attachment, Berglundh et al. (Berglundh et al. 2007) observed epithelial proliferation and the first signs of a barrier (junctional ) epithelium two weeks after implantation. Tissue maturation and collagen fiber organization was evident 6 to 12 weeks of healing.

Epithelial and subepithelial periimplant tissues were not analyzed in details in most investigations. In the experimental study in dogs Ponguarison et al. (Ponguarison et al., 2007) investigated inflammation associated with implants with different surface types inserted in one-stage method. The junctional epithelium and oral epithelium were examined for assessment of the inflammatory infiltrate. The areas of infiltrate were categorized into three grades according to the density of inflammatory cells. Pathohistological findings revealed that the periimplant tissues surrounding all types of abutment surfaces tested, exhibit some degree of inflammation. Subepithelial areas had the greatest density of infiltration ( $3+$ grade). Implants with machined surface with circumferential groove had the largest area of inflammatory infiltrate, but there were no statistically significant differences in number of infiltrating cell types between the four investigated transmucosal surfaces, suggesting that the surface of the implant has little if any influence on the nature of the surrounding inflammation, which is in agreement with the results of numerous authors who studied the influence of implant surface on periimplant soft tissue attachment or the initiation and progression of inflammation (Abrahamsson et al., 2002; Klinge \& Meyle, 2006).

\subsection{Studies on periimplant bone tissue}

Bone is an active biologic tissue that undergoes resorption and remodeling periods in response to various factors. Attention must be paid to maintain bone in a healthy state during the surgical procedure of implant insertion so as not to damage the cell viability and nutrient blood supply to the bone. The use of slow-speed rotary cutting instruments with internally and/or externally applied irrigation provides less amount of cell damage during surgery. Following the osteotomy, the bone must heal around the endosteal implant surface.

The concept of osseointegration arose from the studies of osseous wound healing that had started in the 1950 s by Bränemark. Titanium chambers containing a transillumination system were inserted into the fibulae of rabbits to observe cellular changes during endostael 
wound healing. At the completion of the study, retrieval of the titanium chamber required the fracture of bone tissue that has integrated with the chamber surface. Bränemark's team found that implants made of commercially pure (c.p.) titanium, careful bone preparation and immobilization of the implant during the initial healing phase were necessary to effect a rigid fixation of the implant to the surrounding bone tissue (LeGeros \& Craig, 1993).

Surgical placement of endosteal implants elicits an osteogenic response largely driven by local factors. The initial healing response is independent of direct mechanical control because bone heals optimally in the absence of functional loading. The vascularly dependent ostegenic process can be easily disrupted by micromotion at a healing bone-implant interface. This is one of the main reasons why some surgeons advocate two-stage implant placement. Following a maturation phase of about 1 week newly formed osteoid is primarily mineralized when osteoblasts deposit about $70 \%$ of the mineral found in mature vital bone. Adequate resistance to loading in humans is achieved in about 18 weeks, but there are no quantitative data (Misch, 1999).

Two theories for the mechanism responsible for osteogenesis at implant interface exist in the literature. According to Davies et al. (Davies et al., 1991, as cited in Steflik et al., 1999) there is no fibrillar material directly at the implant-bone interface. Bone derived cells deposit calcified accretions to condition the implant surface prior bone formation, thus no collagen fibers directly interface with the implant. The second theory, based on the studies and investigations of Steflik, Albrektsson and Linde (Steflik et al., 1998; Albrektsson et al., 1981; Linder et al., 1983, as cited in Steflik et al., 1999) suggests that an unmineralized collagen fiber matrix is deposited at the implant interface and is subsequently mineralized.

The aforementioned experimental study of the authors on implant insertion in canine mandibles included pathohistological analyses of three bone regions surrounding implants: bone-to-implant contact region, bone-implant interface and bone tissue adjacent to the implant $(0,03-0,04 \mathrm{~mm})$ aiming specifically to provide information on bone structure, bone maturity and inflammatory reaction.

Analyses were performed on 90 specimens from each of the three bone tissue regions thus comprising 270 specimens. Semi-quantitative analysis was performed for each site (evaluation of the amount of connective - collagen tissue fibers, osteoblastic activity, number of blood vessels, inflammatory cell infiltration, bone tissue necrosis, appearance of blood vessel walls and blood vessel volume) and graded. Quantitative analyses of pathohistological findings were performed according to the established grading indices for each evaluated region. Outcomes of two surgical methods were compared using nonparametric Wilcoxon-Mann-Whitney rank-sum test for two small independent samples.

The analysis of bone-to-implant contact region: With regard to the results obtained on the basis of descriptive statistics, better results were achieved by two-stage method regarding the amount of collagen tissue fibers and this difference was statistically significant while regarding the osteoblastic activity and bone necrosis the results were identical. Pathohistological analysis of the implants inserted in one-stage method revealed increased amount of connective-collagen tissue fibers in 5 specimens. Necrosis was also observed in the same samples. In remainder moderate osteoblastic activity was found (Fig. 7).

The pathohistological findings of bone tissue in contact with the implants inserted in twostage method revealed increased amount of connective-collagen tissue fibers in all specimens. No osteoblastic activity was observed. Partial bone tissue necrosis was found in 8 specimens and in 1 necrosis was complete (Fig. 8). 


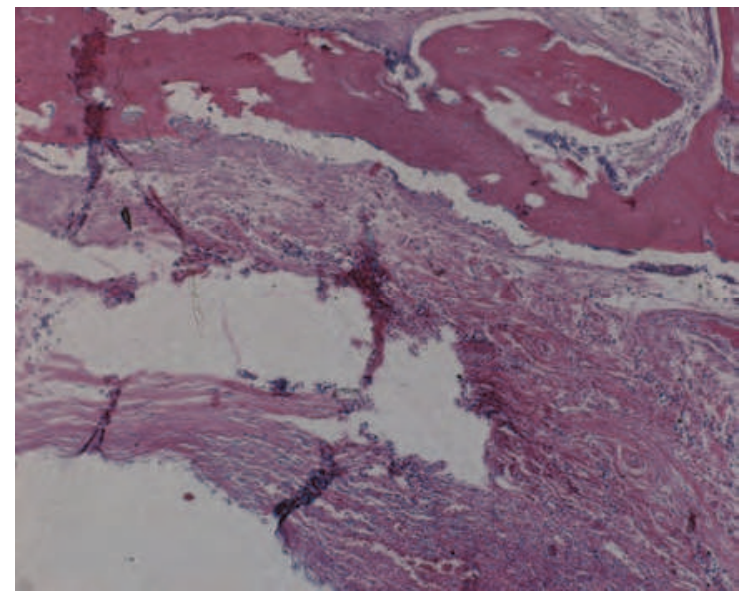

Fig. 7. Increased amount of connective tissue with marked chronic inflammatory cell infiltration, partial necrosis and marked vascular proliferation. Presence of compact bone tissue regions with osteoblastic activity can be detected (HEX40).

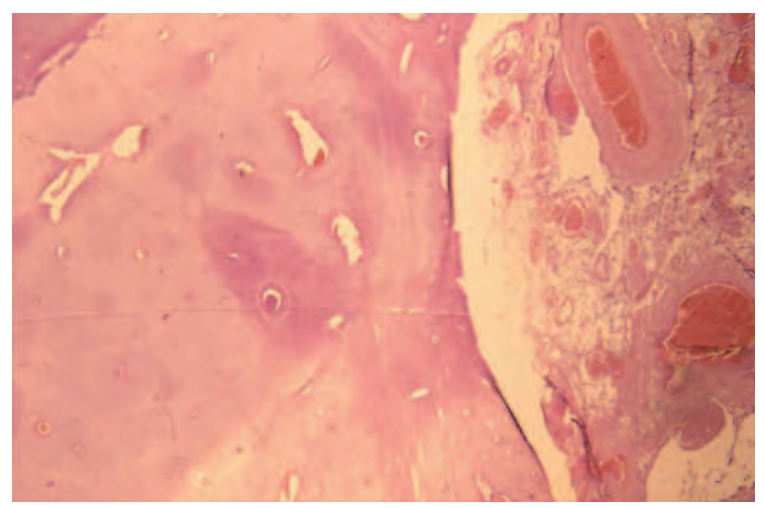

Fig. 8. On the left: compact lamellar bone. On the right: increased amount of connective collagen tissue, with numerous dilated blood vessels, marked inflammatory cell infiltrate and partial necrotic lesions (HE X 40).

The analysis of the bone-implant interface: According to the results on the basis of descriptive statistics the results were identical regarding median values of osteoblastic activity, blood vessels, inflammatory cell infiltrate and bone tissue necrosis. Better results were achieved by two-stage method regarding the amount of collagen tissue, but there were no statistically significant differences between the methods. The pathohstological analysis of bone-implant interface of the implants inserted in one-stage method revealed increased amount of connective-collagen tissue fibers in all specimens, moderate increase of the number of osteoblasts (osteoblastic activity) was observed in 2 specimens Marked neovascularization was found in 2 and moderate in 1 specimen. Inflammation was absent in all specimens, while necrosis was found in only 1 specimen (Fig. 9). 


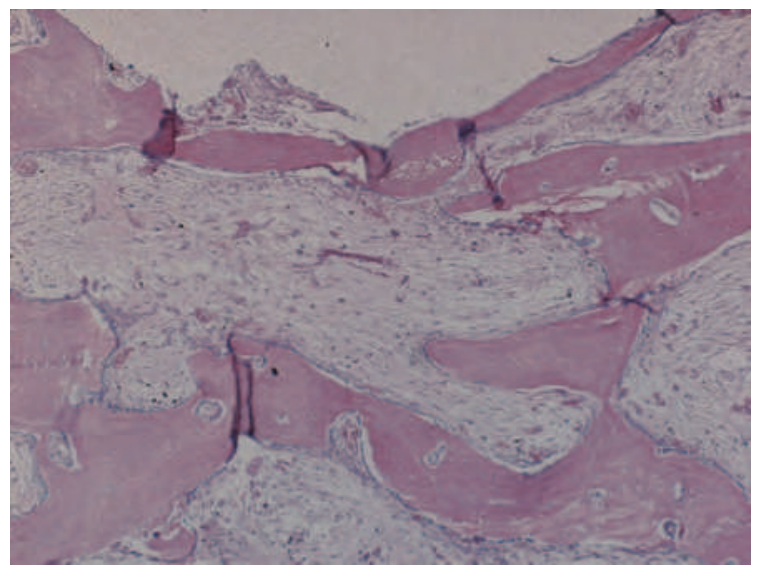

Fig. 9. Marked amount of connective - collagen tissue fibers between bone lamellae with vascular proliferation and marked osteoblastic reaction (HE X 40)

The pathohistological analysis of the implants inserted in two-stage method revealed marked increase of connective tissue fibers in 5 specimens, in 1 specimen moderate increase of osteoblasts was observed, as well as moderate vascular proliferation and marked neovascularization. Inflammation and bone tissue necrosis were also found in only 1 specimen (Fig. 10).

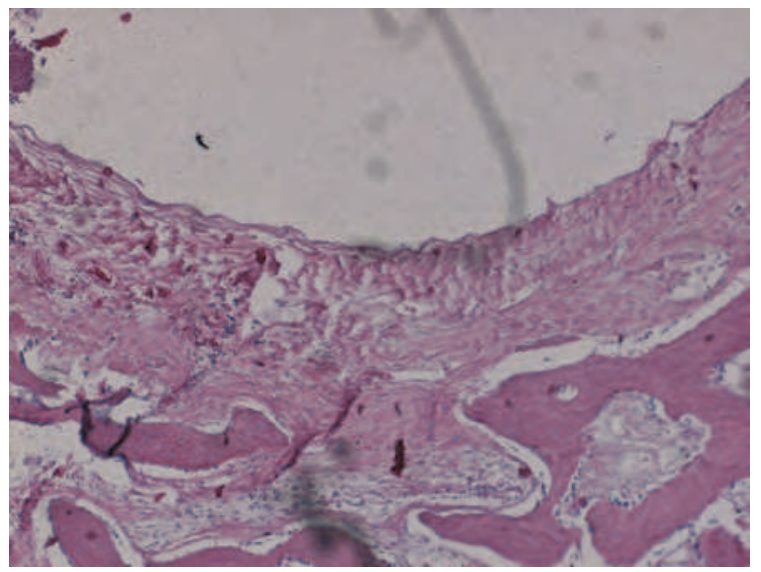

Fig. 10. Loose subepithelial connective tissue. Trabecular bone lattice with collagen tissue proliferation, marked neovascularization, poor osteoblastic activity, moderate inflammatory cell infiltrate and partial bone tissue necrosis (HEX40).

The analysis of bone tissue adjacent to the implant: According to the results on the basis of descriptive statistics the results were identical regarding the median values of amount of collagen tissue, osteoblastic reaction and bone tissue necrosis while better results were achieved regarding the number of osteocytes by two-stage surgical procedure. The latter result was also statistically significant. 
Pathohistological analysis of the implants inserted in one-stage method revealed moderate increase of connective-collagen tissue fibers in only 1 specimen where also no osteoblasts and osteocytes could be observed; moderate increase of osteoblasts and osteocytes was found in 3 samples; the number of osteocytes was increased in 4 specimens. Necrotic bone tissue was not found in any of analyzed specimens. In 1 specimen bone structure was completely preserved with no connective tissue fibers, but with no osteoblasts and osteocytes as well (Fig. 11).

Pathohistological analysis of the implants inserted in two-stage method revealed moderate increase of connective tissue fibers in only 1 specimen. No osteoblastic activity could be observed in all specimens. Moderate increase of osteocytes was observed in 3 specimens and marked increase in 6 remained specimens. Necrotic bone tissue was not found in any of analyzed specimens (Fig. 12).

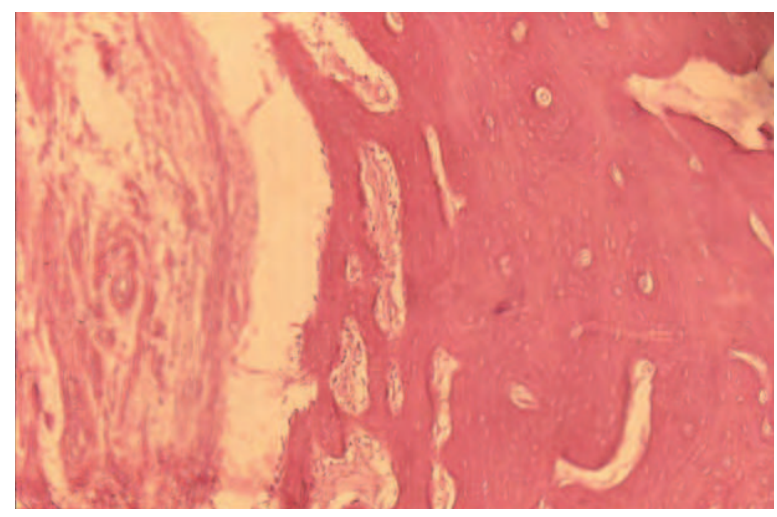

Fig. 11. On the left: loose subepithelial connective tissue, underneath scattered interconnected bone trabeculae with osteoblastic reaction, collagen tissue proliferation between trabeculae. On the right: preserved lamellar bone tissue with osteocytes in lacunae (HEX10).

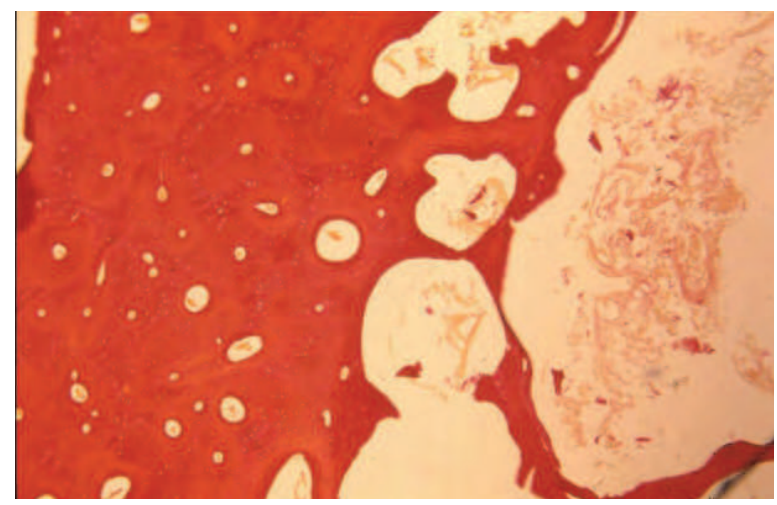

Fig. 12. Mature lamellar bone, underneath interconnected bone trabeculae and intertrabecular collagen tissue proliferation (HE X10). 
Experimental study conducted by Ericsson et al. on Labrador dogs analyzed certain characteristics of periimplant tissues following one- and two-stage surgical installation of Bränemark implants. The results demonstrated that titanium implants can obtain proper bone anchorage (osseointegration) despite being exposed to oral cavity during the initial 3month healing phase (Ericsson et al., 1996).

Implant surface characteristics have been the focus of research in implantology since 1960s. The interrelationship of surgical methods and implant surface was investigated by Levy et al. who analyzed bone-to-implant contact around porous coated root form implants placed in the canine model in one- and two-stage surgical method. After six weeks of healing, the absolute bone-to-implant contact was greater for submerged implants, although significantly on the buccal aspects only (Levy et al., 1996). Similar results were reported by Sagara et al. (Sagara et al.,1993, as cited in Levy et al., 1996) who analyzed bone-to-implant contact of submerged and non-submerged implants placed in dogs after a healing period of 12 weeks. In contrast, Gotfredsen et al. (Gotfredsen et al., 1991, as cited in Levy et al., 1996) found no significant difference between one- and two-stage implant methods in their experimental research on 6 monkeys. Namely, Gotfredsen et al. performed histological evaluations of tissue reactions to unloaded submerged implants without reopening and unloaded non-submerged ITI TPS (titanium plasma spray) implants. After 22 weeks of healing the results indicated that both groups had similar bone levels at the end of healing period and no differences were found in the histological analysis of bone-to-implant contact regions between the implant types. They concluded that osseointegration could be established regardless of the surgical approach. According to Levy et al. (Levy et al., 1996) this difference in protocol may be the important variable in that the long healing period may have provided sufficient time for bone healing to overcome any early inhibitory factors affecting non-submerged implants. Fiorellini et al. (Fiorellini et al., 1999) evaluated the radiographic changes following the insertion of submerged and non-submerged implants in beagle dogs and concluded that there were no differences between the implants on the overall amount and rate of periimplant bone loss, although distinctive patterns of bone resorption existed between the implant types.

The region of bone adjacent to the implant has been investigated in not so many studies. This region is considered a key zone for continued osseointegration of the implant. One of the studies investigating the bone tissue supporting the implant is the one conducted by Meenaghan (Meenaghan, 1974, as cited in Steflik et al., 1999) who first described a triple layer of osseous cells in the remodeling process close to blade implant. He suggested that an outer dense cellular layer existed comprised of mesenchymal-like cells interfaced with the implant. A middle layer of highly vascularized osteogenic tissue existed to a third layer of osteoblasts associated with osteoid matrix and bone. Similar findings were reported by Steflik et al. who observed osteoblastic activity in the zone adjacent to implant. (Steflik et al., 1994, as cited in Steflik et al., 1999).

Investigating crestal bone changes around titanium submerged and non-submerged implants in canine mandibles histomorphometrically, Hermann et al. (Hermann et al., 2000) concluded that bone changes were not dependent on the surgical technique (one- and twostage insertion).

Koch et al. (Koch et al., 2010) investigated the osseointegration of the implants of different materials inserted in one- and two-stage surgical procedure in dogs. Healing modalities did 
not influence the rate of bone-to-implant contact between the implants, among which were the implants of c.p. titanium.

\subsection{Future research}

Oral implants have developed rapidly. New technical and technological improvement upon diagnostic tools and medical equipment have considerably reduced the risk of operative complications. Basic studies within physical and biologic sciences have resulted in development of various surgical implant systems where special attention has been paid to surface topography and technology as well as to the processes of wound healing along biomaterial interfaces.

Currently direct bone-to-implant contact is considered the optimal healing outcome around endosteal implants. The character of tissues around the implants and the quality of tissue attachment to the implant surface influence the biomechanical response of this integration.

The interfacial interactions between recipient tissues and implanted material are limited to the surface layer of the implant and a few nanometers into the living tissue. The surface property has been recognized as important factor for successful osseointegration because it can promote early and secure bone formation around dental implants. Titanium is by far the material of choice for dental implants and various surface treatments have been proposed to enhance the osseointegration: blasting of the surface, acid or fluoride etching or anodizing. In recent years chemically modified surfaces have been proven to enhance bone-to-implant contact. These modifications increase the hydrophilic property of titanium surfaces and accelerate and enhance the initial adsorption of extracellular matrix proteins (Rupp et al., 2004; Buser et al., 2004, as cited in Jimbo et al., 2011). In their experimental study on Japanese White rabbits Jimbo et al. (Jimbo et al., 2011) investigated bone apposition during the early phases of osseointegration of anodized porous titanium implants modified with hydrogen fluoride solution and ultraviolet irradiated. Histomorphometric analyses revealed that photo-induced hydrophilic surface enhanced bone apposition thus shortening the healing period. In addition, photo-reactive implant surface provide photo-induced sterilization as well as a decontamination of infected implant parts (eg. transmucosal abutments) by simple irradiation.

Recently, much attention has been given to implant surface treatment with biologically active substances. These include purified proteins and synthetic peptides that mediate the binding of osteoblast cell adhesion receptors. When dental implants inserted into the bone a sequence of cellular and molecular events are involved. Undifferentiated mesenchymal cells proliferate and migrate into the implant socket from adjacent marrow, endosteum and periosteum. These cells differentiate into osteoblasts or osteoclasts under the influence of locally acting growth factors, leading to bone maturation and mineralization. Bone morphogenetic proteins (BMPs) are members of the TGF- $\beta$ (transforming growth factor) - $\beta$ super family, a group of cytokines with the expression in various tissues. They have numerous functions, among which is to induce the osteoblasts to differentiate and form bone tissue (Asahina et al., 1996; Yamaguchi et al., 1996).

In their study on the influence of recombinant human BMP-2 (rhBMP-2) on bone-implant osseointegration, Lan et al. (Lan et al., 2007) investigated whether osseointegration can be enhanced by the use of rhBMP-2. Titanium implants were coated by rhBMP-2 with 
polylactic acid as a carrier. The results showed that osseointegration was improved in quality as well as in quantity, however further studies are necessary to evaluate the optimal dose range of rhBMP-2 and research new carriers.

Most studies evaluating growth, differentiation and matrix factor as potential agents in support alveolar bone augmentation have focused on rhBMP-2, but it is not the only member of BMP family of proteins approved for clinical use. Susin et al. (Susin et al., 2010) have used rhBMP-7 (also known as recombinant human osteogenic protein - rhOP-1) coated onto the titanium porous-oxide surface implants to attain vertical alveolar ridge augmentation and implant osseointegration. Two different doses of BMP-7 were compared. No statistically significant differences were observed. Both doses produced clinically relevant bone formation. The authors concluded that rhBMP-7 coated onto titanium implants exhibits a convincing potential to stimulate local bone formation. Lee et al. (Lee et al., 2010) also investigated osseointegration of implants coated with rhBMP-2 and concluded that significant bone formation was achieved. Huh et al. (Huh et al., 2010) investigated the effects of anodized implants coated with Escherichia coli-derived rhBMP-2 (ErhBMP-2) on alveolar ridge augmentation in beagle dogs. The results suggest that ErhBMP-2 can induce vertical bone augmentation when placed in the vertical defects of alveolar bone that has been healed after tooth extraction thus improving the stability of implants and excluding the need for additional bone transplantation.

Functioning arrangement of connective tissue around endosteal implants that would act as a periodontal ligament does not exist, but the efforts are made in order to make an implant resemble a natural tooth. One direction of investigations is to regenerate periodontal ligament from periodontal cells (for example in immediate implantation) and the other direction is from mesenchymal stem cells or periodontal progenitor cells.

Early experimental studies on new formation of periodontal ligament have started in 1980s. Those studies indicated that only cells residing in PDL (periodontal ligament) were capable of forming new cementum with inserting collagen fibers on exposed root surfaces. Periodontal ligament is lost with the natural tooth loss, it cannot be restored after implant placement. Buser et al. (Buser et al., 1990) analyzed the wound healing around titanium implants in the presence of retained root tips. The experiment was performed on 5 monkeys. After a period of 12 months pathohistologic examination revealed that in regions the implants were placed close to retained roots, a periodontal ligament had formed around large portions of the implant. In polarized light it was apparent that the collagen fibers were oriented perpendicularly to the implant surface and were inserted in the cementum on the implant surface as well as in the opposing bone.

The discovery of a periodontal ligament around titanium implants opens new perspectives in implantology. Parlar et al. (Parlar et al., 2005) performed unique experiment on mongrel dogs to explore the formation of periodontal tissues around titanium implants using maxillary canine roots. They created chambers within the roots and prepared slits in the cavity walls to connect the chamber to the periodontal space. Implants were placed into the center of each chamber. Following 4 months of healing pathohistological analysis was performed. Fibrous encapsulation was observed around most implants, but cellular cementum was deposited on 2 implants, most likely formed through cementoconductivity rather than by differentiation of periodontal ligament cells upon contact with the implant surface. Partial generation of periodontal ligament on endosteal dental implants in dogs was 
also observed by approximating a tooth-to-implant contact using orthodontics (Jahangari et al., 2005).

In a pilot experimental study Craig et al. (Craig et al., 2006) reported on the effect of autogenous periodontal cell grafts on the implant-connective tissue interface with and without enamel matrix derivative (EMD). After 8 weeks histomorphometric and microscopic analyses revealed that EMD and the type of cell population present in the implant wound-healing environment may alter the implant-connective tissue interface.

Technically implant carrying periodontal ligament (PDL) may be inserted in the extraction socket of the missing tooth. One of the recent investigations regarding a tissue-engineered periodontal ligament around dental implants was performed by Gault et al. (Gault et al., 2010). They developed so called "ligaplant" which is the combination of PDL cells with the implant biomaterial. Following implant placement a new PDL-like tissue is produced. The authors claim that ligaplants have the capacity to induce the formation of new bone tissue. Investigations were performed in animal and human models. Hydroxyapatite (HAP)coated titanium implants were combined with canine-derived PDL cells and inserted into the jaws of respective cell donors. The dogs were sacrificed after 20 weeks and pathohistological analyses were performed on 11 implants. The results indicated that the formation of PDL-like tissue can be attained in vivo, if a suitable implant surface and sufficient amounts of PDL cells are provided. A PDL-like tissue was formed with perpendicular fibers between the implant and alveolar bone. However, formation of this tissue is a slow process.

Dental and non-dental derived stem cells have the periodontal regeneration capability. As Liu et al. suggested in their study on miniature pigs, autologous periodontal ligament stem cells (PDLSC) are capable of forming bone, cementum and PDL if they are transplanted onto to HA/TCP (hydroxyapatite/tricalciumphosphate) carrier into surgically created periodontal defects (Liu, 2008, as cited in Batistella et al., 2010). PDLSC used with HA/TCP as a carrier showed the capacity to differentiate into cementoblasts and to form cementum/PDL-like structures (Batistella et al., 2010). These cells (PDLSC) also have the capacity to form collagen fibers similar to Sharpey's fibers and suggest the potential to regenerate PDL attachment.

Non-dental derived stem cells have also been the source of periodontal regeneration cells. Marei et al. (Marei et al., 2005) investigated the formation of periodontal structure around titanium implants utilizing bone marrow mesenchymal stem cells (MSCs). In their pilot experimental study on goats they placed immediate implants after canine teeth extractions bilaterally. Experimental side received a porous hollow root-form poly DLLactide co-Glycolide scaffold with autogenous bone-marrow-derived mesenchymal stem cells. The results showed that periodontal-like tissue with newly formed bone was observed. The authors concluded that undifferentiated MSCs were capable of differentiating to provide three critical tissues required for periodontal tissue regeneration: cementum, bone and periodontal ligament. Adipose-derived stem cells were used in a work of Tobita combined with platelet-rich plasma (PRP) and implanted into the periodontal tissue defects in rats. Partial alveolar bone regeneration and a periodontal ligament-like structure were observed 8 weeks after implantation (Tobita et al., 2008, as cited in Batistella et al., 2010).

However the precautions must be taken, since using stem cells may have some risks. Carcinoma-associated fibroblasts (CAF) play important role in the growth of epithelial solid 
tumors. Although the cell type of origin of CAFs has not been conclusively established it has been shown that they may be marrow derived. When cultured in conditioned medium MSCs) derived from cancer cell lines for prolonged periods, assume CAF properties. These activated MSCs have increased expression of CAF markers and in addition, support growth of breast cancer cells in vitro as well as in vivo in xenograft model (Mishra et al., 2009).

\section{Conclusion}

Over the past few decades, an improved understanding of the various parameters that influence osseointegration has resulted in high predictability and clinical success of dental implants. One- and two-stage implant insertion give acceptable results regarding certain important characteristics of investigated soft and bone periimplant tissues (epithelial basal membrane structure, inflammatory reaction, tissue degradation and/or necrosis, osteoblastic activity, collagen tissue proliferation, neovascularization). Most of the experimental study designs area based on a limited number of investigated samples, so there are no significant differences between the two methods.

Numerous other phenomena that occur after the functional loading of implants are common for all implant systems, irrespective of the method of their surgical placement. Moreover, it seems that surgical methods are of lesser importance for the long term implant maintenance compared with implant design characteristics, especially those related to their surface. Ultimately, with the increasing knowledge about tissue engineering, when tooth loss does occur, regeneration of the entire tooth may be advantageous in comparison with replacement by implants.

\section{Acknowledgement}

The authors would like to thank Prof. Vujadin Tatić, Ph.D. for his assistance in histology preparations and Mr. Dušan Stanković for his valuable contribution to the statistical analysis and technical assistance in manuscript preparation.

\section{References}

Abrahamsson, I., Berglundh, T., Wennstrom, J. \& Lindhe, J. (1996). The peri-implant hard and soft tissues at different implant systems. Comparative study in the dog. Clin. Oral Impl. Res, Vol. 7, No 3 , (September 1996), 212-219, ISSN 0905-7161

Abrahamsson, I., Berglundh, T., Moon, IS. \& Lindhe, J. (1999). Periimplant tissues at submerged and non-submerged titanium implants. J Periodontol, Vol. 26, No 9, (September 1999), 600-607, ISSN 0303-6979

Abrahamsson, I., Zitzmann, NU., Berglundh, T., Linder, E., Wennerberg, A. \& Lindhe, J. (2002). The mucosal attachment to titanium implants with different surface characteristics: an experimental study in dogs. J Clin Periodontol, Vol. 29, No. 5, (May 2002), 448-455, ISSN 0303-6979 
Abrahamsson , I. \& Cardarpoli G. (2007). Peri-implant hard and soft tissue integration to dental implants made of titanium and gold. Clin. Oral Impl. Res, Vol. 18, No 3, (June 2007), 269-274, ISSN 0905-7161

Asahina, I., Sampath, TK. \& Hauschka, PV. (1996). Human osteogenic protein-1 induces chondroblastic, osteoblastic and/or adipocytic differentiation of clonal murine target cells. Exp Cell Res, Vol. 222, No. 1, (January 1996), 38-47, ISSN 0014-4827

Batistella, E., Mele, S. \& Rimondini, L. (2010). Dental tissue engineering: a new approach to dental tissue reconstruction. In: Biomimetics Learning from Nature, Editor Amitava Mukherjee, InTech, (March 2010), ISBN 978-953-307-025-4, Wienna, Austria

Berglundh, T., Abrahamsson, I., Welander, M., Lang, N. \& Lindhe, J. (2007). Morphogenesis of the peri-implant mucosa: an experimental study in dogs. Clin.Oral Impl. Res, Vol. 18, No. 1, (February 2007), 1-8, ISSN 0905-7161

Bräger, U., Häfeli, U., Huber, B., Hämmerle, CHF. \& Lang, N. (1998). Evaluation of postsurgical crestal bone levels adjacent to non-submerged dental implants. Clin.Oral Impl. Res, Vol. 9, No. 4, (August 1998), 218-224, ISSN 0905-7161

Buser, D., Warrer, K. \& Karring, T. (1990). Formation of a Periodontal Ligament around Titanium Implants. J Periodontol, Vol. 61, No. 9 (September 1990), 597-601, ISSN 0022-3492

Buser, D., Mericke-Stern, R., Dula, K. \& Lang, N. (1996). Clinical Experience with One-stage, Non-submerged Dental Implants. Adv Dent Res, Vol. 13, No. 1, (June 1999), 153-161, ISSN 0895-9374

Cochran, DL., Hermann, JS., Schenk, RK., Higginbottom, FL. \& Buser, D. (1997). Biologic width around titanium implants. A histometric analysis of the implanto-gingival junction around unloaded and loaded nonsubmerged implants in the canine mandible. J Periodontol, Vol. 68, No 2, (February 1997), 186-198, ISSN 0022-3492

Craig, RG., Kamer, AR., Kallur, SP., Inoue, M. \& Tarnow, DP. (2006). Effects of Periodontal Cell Grafts and Enamel Matrix Proteins on the Implan-Connective Tissue Interface: A Pilot Study in the Minipig. J Oral Implant, Vol. 32, No. 5, 228236, ISSN 1048-1842

Ericsson, I., Nilner, K., Klinige, B. \& Glantz, P-O. (1996). Radiographical and histological characteristics of submerged and nonsubmerged titanium implants. An experimental study in the Labrador dog. Clin. Oral Impl. Res, Vol. 7, No 1, ( March 1996), 20-26, ISSN 0905-7161

Fartash, B., Arvidson, K. \& Harmann, DJ. (1990). Histology in tissues surrounding single crystal sapphire endosseous dental implants. Clin. Oral Impl. Res, Vol. 1, No. 1, (December 1990), 13-21, ISSN 0905-7161

Fiorellini, JP., Buser, D., Paquette, DW., Williams, RC., Haghighi, D. \& Weber, HP. (1999). A Radiographic Evaluation of Bone Healing around Submerged and Non-Submerged Dental Implants in Beagle Dogs. J Periodontol, Vol. 70, No. 3 (March 1999), 248-254, ISSN 0022-3492

Gault, P., Black, R., Romette, J-L., Fuente, F., Schroeder, K., Thilou, F. et al. (2010). Tissue engineered ligament: implant constructs for tooth replacement. J Clin Periodontol, Vol. 37, No. 8, (August 2010), 750-758, ISSN 0303-6979 
Hermann, JS, Buser, D., Schenk, RK., Higginbottom, FL., \& Cohran, DL. (2000). Biologic width around titanium implants. A physiologically formed and stable dimension over time. Clin. Oral Impl. Res, Vol. 11, No. 1, (February 2000), 1-11, ISSN 09057161

Hermann, JS., Buser, D., Schenk, RK. \& Cochran, DL. (2000). Crestal bone changes around titanium implants. A histometric evaluation of unloaded submerged and nonsubmerged implants in the canine mandible. J Periodontol, Vol. 71, No.9, (September 2000), 1412-1424, ISSN 0022-3492

Hermann, JS., Buser, D., Schenk, RK., Schoolfield, JD. \& Cochran, DL. (2001). Biologic Width around one- and two-piece titanium implants. A histometric evaluation of unloaded nonsubmerged and submerged implants in canine mandible. Clin. Oral Impl. Res, Vol. 12, No. 6, ( December 2001), 559-571, ISSN 0905-7161

Heydenrijk, K.,Raghoebar, GM., Meijer, HJ., van der Reijden, WA., van Winkelhoff., AJ. \& Stegenga, B. (2002). Two-stage IMZ implants and ITI implants inserted in a single stage procedure. A prospective comparative study. Clin. Oral Impl. Res, Vol. 13, No. 4, (August 2002), 371-380, ISSN 0905-7161

Huh, JB., Park, CK., Kim, SE., Shim, KM., Choi, KH., Kim, SJ. et al. (2010). Alveolar ridge augmentation using anodized implants coated with Escherichia coli - derived recombinant human bone morphogenetic protein 2. Oral Surg Oral Med Oral Pathol Oral Radiol Endod, in press, doi: 10.1016/ij.tripleo.2010.09.063

Jahangiri, L., Hessamfar, R. \& Ricci, JL. (2005). Partial generation of periodontal ligament on endosseous dental implants in dogs. Clin. Oral Impl. Res, Vol. 16, No. 4 , (August 2005), 394-401, ISSN 0905-7161

James, RA. \& Kelln, E. (1974). A histopathological report on the nature of the epithelium and underlining connective tissue which surrounds implant posts. J Biomed Mat Res, Vol. 8, No. 4, 385-390, ISSN 1097-4636

Jimbo, R., Ono, R., Hirakawa, Y., Odatsu, T., Tanaka, T. \& Sawase, T. (2011). Accelerated Photo-Induced Hydrophilicity Promotes Osseointegration: An Animal Study. Clin Implant Dent and Rel Res, Vol. 13, No. 1, (March 2011), 79-85, ISSN 1523 0899

Klinge, B. \& Meyle, J. (2006). Soft tissue integration of implants. Consensus report of Working Group 2. Clin. Oral Impl. Res, Vol. 17 (Suppl.), No S2, (October 2006), 9396, ISSN 0905-7161

Koch, FP., Weng, D., Kramer, S., Biesterfeld, S., Jahn-Eimermacher A. \& Wagner, W. (2010). Osseointegration of one-piece zirconia implants compared with a titanium implant of identical design: a histomorphometric study in the dog. Clin. Oral Impl. Res, Vol. 21, No. 4, (April 2010), 350-356, ISSN 0905-7161

Lan, J, Wang, ZF., Shi., Xia, HB. \& Cheng, XR. (2007). The influence of recombinant human BMP-2 on bone-implant osseointegration: biomechanical testing and histomorphometric analysis. Int. J. Oral Maxillofac. Surg. Vol. 36, No.4, (April 2007), 345-349, ISSN 0901-5027

Lee, J., Decker, JF., Polimeni, G., Cortella, CA., Rohrer, MD., Wozney, JM et al. (2010). Evaluation of implants coated with rhBMP-2 using two different coating strategies: 
a critical-size supraalveolar peri-implant defect study in dogs. J Clin Periodont, Vol. 37, No. 6, (June 2010), 582-590, ISSN 0303-6979

Levy, D., Deporter, DA., Piliar, RM., Watson, PA. \& Valiquette, N. (1996). Initial healing in the dog of submerged versus non-submerged porous-coated endosseous dental implants. Clin. Oral Impl. Res, Vol. 7, No 2, (June 1996), 101 - 110, ISSN 0905-7161

LeGeros, RG. \& Craig, RG. (1993). Strategies to Affect Bone Remodeling: Osteointegration. J Bone Min Res, Vol. 8, No S2, (December 1993), S583-S596, ISSN 0884-0431

Linquist, LW., Carlsson, GE. \& Jemt, T. (1996). A prospective 15-year follow-up study of mandibular fixed prostheses supported by osseointegrated implants. Clinical results and marginal bone loss. Clin. Oral Impl. Res, Vol. 7, No. 4, (December 1996), 329-336, ISSN 0905-7161

Marei, KM., Saad, MM., El-Ashwah, AM., El-Backly, RM \& Al-Khodary, MA. (2009). Experimental Formation of Periodontal Structure Around Titanium Implants Utilizing Bone Marrow Mesenchymal Stem Cells: A Pilot Study. J Oral Implant, Vol. 35, No. 3, 106-129, ISSN 1048-1842

Micsh, CE. (1999). Contemporary Implant Dentistry, Second Edition, Mosby Inc., ISBN 08151-7059-9, St. Louis, USA

Mishra, PJ., Mishra PJ. \& Glod, JW. (2009). Mesenchymal Stem Cells: Flip Side of the Coin. Cancer Res, Vol.69, No. 4, (Febraury 2009), 1255-1257, ISSN 0008- 5472

Moon, I-S., Berglundh, T., Abrahamsson, I. \& Linder J. (1999). The barrier between the keratinized mucosa and the dental implant. An experimental study in the dog. $J$ Clin Periodontol, Vol. 26, No. 10, (October 1999), 658-663, ISSN 0303-6979

Parlar, A., Bosshardt, DD., Ünsal, B., Çetiner,D., Haytaç, C. \& Lang, NP. (2005). New formation of periodontal tissues around titanium implans in a novel dentin chamber model. Clin. Oral Impl. Res, Vol. 16. No. 3, ( June 2005), 259-367, ISSN 09057161

Ponguarison, NJ., Gemmell, E., Tan, AES., Henry, PJ., Marshall, RI. \& Seymour, GJ. (2007). Inflammation associated with different surface types. Clin. Oral Impl. Res, Vol. 18, No. 1, (February 2007), 114-125, ISSN 0905-7161

Steflik, DE., Corpe, RS., Young, TR., Sisk, AI. \& Parr, GR. (1999), The Biologic Tissue Responses to Uncoated and Coated Implanted Biomaterials. Adv Dent Res, Vol. 13, No. 1, (June 1999), 27-33, ISSN 0895-9374

Susin, C., Qahash, M., Polimeni, G., Lu, PH., Prasad, HS., Rohrer, MD. et al. (2010). Alveolar ridge augmentation using implants coated with recombinant human bone morphogenetic protein-7 (rhBMP-7/rhOP-1): histological observations. J Clin Periodont, Vol. 37, No. 6, (June 2010), 574-581, ISSN 0303-6979

Weber, HP., Buser, D., Donath, K., Fiorellini, JP., Doppalapudi, V., Paquette, DW. \& Williams, RC. (1996). Comparison of healed tissues adjacent to submerged and non-submerged titanium implants. A histometric study in beagle dogs. Clin. Oral Impl. Res, Vol. 17, No 1, ( March 1996), 11-19, ISSN 0905-7161

Weber, HP. \& Cochran DL. (1998). The soft tissue response to osseointegrated dental implants. J Prosthet Dent. Vol. 79, No. 1, (January 1998), 79-89, ISSN 0022-3913 
Yamaguchi, A., Ishizuya, T., Kintou, N., Wada, Y., Katagari, T., Wozney, JM. et al. (1996). Effects of BMP-2, BMP-4 and BMP-6 on osteoblastic differentiation of bone marrow-derived stromal cell lines, ST2 and MC3T3-G2/PA6. Biochem Biophys Res Commun, Vol. 220, No. 2, (March 1996), 336-371, ISSN 0006-291X 


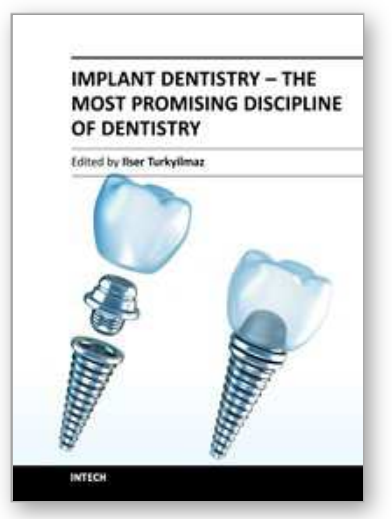

\author{
Implant Dentistry - The Most Promising Discipline of Dentistry \\ Edited by Prof. Ilser Turkyilmaz
}

ISBN 978-953-307-481-8

Hard cover, 476 pages

Publisher InTech

Published online 30, September, 2011

Published in print edition September, 2011

Since Dr. Branemark presented the osseointegration concept with dental implants, implant dentistry has changed and improved dramatically. The use of dental implants has skyrocketed in the past thirty years. As the benefits of therapy became apparent, implant treatment earned a widespread acceptance. The need for dental implants has resulted in a rapid expansion of the market worldwide. To date, general dentists and a variety of specialists offer implants as a solution to partial and complete edentulism. Implant dentistry continues to advance with the development of new surgical and prosthodontic techniques. The purpose of Implant Dentistry - The Most Promising Discipline of Dentistry is to present a comtemporary resource for dentists who want to replace missing teeth with dental implants. It is a text that integrates common threads among basic science, clinical experience and future concepts. This book consists of twenty-one chapters divided into four sections.

\title{
How to reference
}

In order to correctly reference this scholarly work, feel free to copy and paste the following:

Smiljana Matić, Novak Stamatović, Zoran Tatić and Aleksandra Petković-Curčin (2011). Implant Insertion Methods and Periimplant Tissues - Experimental Study, Implant Dentistry - The Most Promising Discipline of Dentistry, Prof. Ilser Turkyilmaz (Ed.), ISBN: 978-953-307-481-8, InTech, Available from:

http://www.intechopen.com/books/implant-dentistry-the-most-promising-discipline-of-dentistry/implantinsertion-methods-and-periimplant-tissues-experimental-study

\section{INTECH}

open science | open minds

\section{InTech Europe}

University Campus STeP Ri

Slavka Krautzeka 83/A

51000 Rijeka, Croatia

Phone: +385 (51) 770447

Fax: +385 (51) 686166

www.intechopen.com

\section{InTech China}

Unit 405, Office Block, Hotel Equatorial Shanghai

No.65, Yan An Road (West), Shanghai, 200040, China

中国上海市延安西路65号上海国际贵都大饭店办公楼405单元

Phone: +86-21-62489820

Fax: $+86-21-62489821$ 
(C) 2011 The Author(s). Licensee IntechOpen. This chapter is distributed under the terms of the Creative Commons Attribution-NonCommercialShareAlike-3.0 License, which permits use, distribution and reproduction for non-commercial purposes, provided the original is properly cited and derivative works building on this content are distributed under the same license. 